\title{
A MAGYARORSZÁGI K+F HELYZETE, EURÓPAI UNIÓS TÜKÖRBEN
}

\author{
Dr. Prof. Balogh Sándor ' \\ professor emeritus, Szegedi Tudományegyetem Mérnöki Kar
}

\section{Summary}

The situation and efficiency of R \& D activities in Hungary were analysed with the use of Eurostat and Central Statistical Office data. The conclusion was drawn that the system of indexes used and published officially is hardly suitable for presenting the existing problems and for carrying out strategic analyses. The analysis of the official data leads to the conclusion that it would be advisable to use long statistical time series and to apply indexes showing specific development more extensively. The situation of R \& D in Hungary is presented in the paper from this approach.

We have found that certain problems hindering $R$ \& $D$ in Hungary, such as the insufficient concentration of researches, the insufficient proportion of business-like researches and researches promising direct economic benefits in general, the problems of the distribution of research investments between fields of science etc., could not be solved in the period after the change of the regime, either. In many respects the current situation of $R \& D$ is definitely worse than before the change of the regime, first of all as concerns the financing of $R \& D$. The dominance of publicationcenteredness as one of the approaches indicating efficiency may overshadow the fundamental duality in the relationship of R \& D with economy, namely that economy should be not only the source but also the primary beneficiary of R \& D activities.

\begin{abstract}
Budapestre költözik az Európai Unió kutatás-fejlesztési központja. A $K+F$ központ költségvetése 2013-ig 308,7 millió euró (mintegy 77 milliárd forint) lesz. Ebbōl a központ müködésére nagyjából 50 millió eurót fordítanak, míg a többit várhatóan az európai tudás- és innovációs társulások (KIC-ek) felállitására és müködtetésére költik majd. Ezek az egyetemek, kutatóintézetek és vállalatok partnerségén alapuló társulások végzik a szakmai munkát. A következó öt évben maximum három társulást fognak létrehozni, egy a klímaváltozás, egy az energia és valószínüleg egy az infokommunikáció területén.

(Ujsághir, 2008 jünius 18)
\end{abstract}

E tanulmány céljai a következők:

1. Áttekintést adni a magyarországi $\mathrm{K}+\mathrm{F}$ helyzetéről, más EU-tagországokhoz is viszonyítva. Összehasonlitani az uralkodó trendeket, minősíteni a magyarországi helyzetet néhány évtizedes történeti távlatban is.

2. Áttekinteni a $\mathrm{K}+\mathrm{F}$ fejlettségét jellemzö mutatórendszert, kritikailag értékelni azt, javaslatot tenni annak kiegészítésére újfajta, a helyzetelemzést jobban szolgáló mutatókkal.

Anyag és módszer. A dolgozat adatbázisát a KSH és az Eurostat adat-gyüjteményei képezik, a publikált és itt idézett „hivatalos” helyzetelemzések is ugyanezen forrásokból származnak. Erre az adatbázisra épitettünk az általunk kidolgozott fejlettségi mutatók esetében is. A magyarországi helyzet értékeléséhez a publikált adatokon kívül (esetenként kéziratos formájú) szakértői anyagok megállapításait, az OECD és az Európai Bizottság állásfoglalásait is használtuk. Megjegyzendő, hogy sem a hazai, sem az EU elemzések során nem leltünk 
olyan adatbázisra, amely az e dolgozatunkban bemutatott részletező számításokra ugyanabban az évben tartalmaztak volna információkat. ${ }^{2}$

Az innovációs fejlettség jellemzésére különbözỏ mutatók használatosak az Európai Unióban és ennek megfelelően Magyarországon, a hazai statisztikai gyakorlatban is. Ezek a mutatók céljaik szerint- a következöképpen csoportosíthatók:

A./ A K $+\mathrm{F}$ tevékenység anyagi és személyi feltételei

B./ A K+F tevékenység „eredményessége”, hatása, következményei.

A $\mathrm{K}+\mathrm{F}$ helyzetelemzést a következő tartalmi elemekböl építettük fel:

A 1 . A K $+\mathrm{F}$ ráforditások ,intenzitásának" minösitése

A/2. A kutatási ráforditások forrás szerinti megoszlása

A/3. A kutatási ráfordításoknak a különböző kutatási szintek közötti megoszlása

A/4. A K+F-ben foglalkoztatott munkavállalók száma

A/5. A kutatói létszám megoszlása a különbözö tudományterületek között

A/6. A kutatóhelyek és a kutatási témák száma.

$\mathrm{A} \mathrm{K}+\mathrm{F}$ tevékenység eredményességét az alábbi jellemzőkkel kívánjuk minősíteni:

B./1. A tudományos publikációk száma

B./2. Az innovatív vállalatok száma

$\mathrm{B} / 3$. A találmányok száma.

A hazai statisztikák és az Eurostat kiadványai általában az elsỏ csoporthoz tartozó információkat (a $\mathrm{K}+\mathrm{F}$ tevékenység anyagi és személyi feltételei) adják közre. Többnyire statikus szemléletúek, egy állapot bemutatására szolgálnak, stratégiai elemzés céljára kevéssé alkalmasak. Ez jelentös ellentmondásnak tünik a Lisszaboni Nyilatkozat és az annak kudarcát követő kijózanodás fényében. Az alapadatokra támaszkodva azonban dinamikus elemzések készíthetők, amelyek az erőviszonyok valósághüebb bemutatását is lehetővé teszik. Éppen ez utóbbi tekinthető dolgozatunk egyik céljának, s ennek érdekében alkottunk ụj mutatókat is.

A/1. A K+F ráfordítások ,intenzitásának" minősítése. Ez nem más, mint a $K+F-r e$ fordított összegek százalékos viszonyítása a megtermelt nemzeti jövedelemhez (GDP-hez). A legáltalánosabban használt - és a szerző szerény véleménye szerint - a legkevésbé használható mutató. Használhatósági korlátja abban áll, hogy nem árul el semmit a vetítési alapról, azaz az ország GDP-jéről. A K+F erőforrások mértékét, azaz az ország kutatási potenciálját ez a mutató nem képes jellemezni, nemzetközi összehasonlításokra nem alkalmas. Ennek ellenére ide kívánkozik néhány adat. A kutatási „piac” fö szereplöi a nagyhatalmak, közéjük sorolhatjuk az Európai Uniót is. Japán ebben az évezredben a nemzeti jövedelem 3 \%-át kitevő összeget, az USA - monoton csökkenő módon - 2,7-2,8 \%-ot, Japán, Kína 1,3 \%-ot , míg az Európai Unió 1,9\% körüli GDP-hányadot fordít K+F-re (1. ábra)

Magyarországon a $\mathrm{K}+\mathrm{F}$ ráfordítások, ,intenzitása" 2006-2007-ben $1 \%$ körüli volt; amely az EU-27 átlagának $(1,84)$ mintegy a fele és ezzel a nagyságrenddel az EU-27-ben a 17. helyen állunk. Az EU-27 tagországai 2005-ben mintegy 200 milliárd euro összeget fordítottak K+Fre. Magyarországon 2007-ben 245,6 milliárd $\mathrm{Ft}$ volt a $\mathrm{K}+\mathrm{F}$ ráfordítás, durván számitva tehát mintegy 1 milliárd euro, azaz az EU-27-nek az 1/200-ad része, 0,5\%-a. Ez lényegesen kisebb, mint akár a népességböl, akár a nemzeti jövedelemböl való részesedésünk. A hazai $\mathrm{K}+\mathrm{F}$ ráfordítások GDP-hez viszonyított aránya az 1980-as évek közepén volt a legmagasabb 
(1,3\%-nál nagyobb); és 1996-ban a legalacsonyabb: 0,67\%, azóta gyengén emelkedō, 0,9 10,0 százalék körüli.

1. ábra: A nemzeti jövedelemből K+F-re fordított hányad: Japán, USA, EU-27, Kína adatai

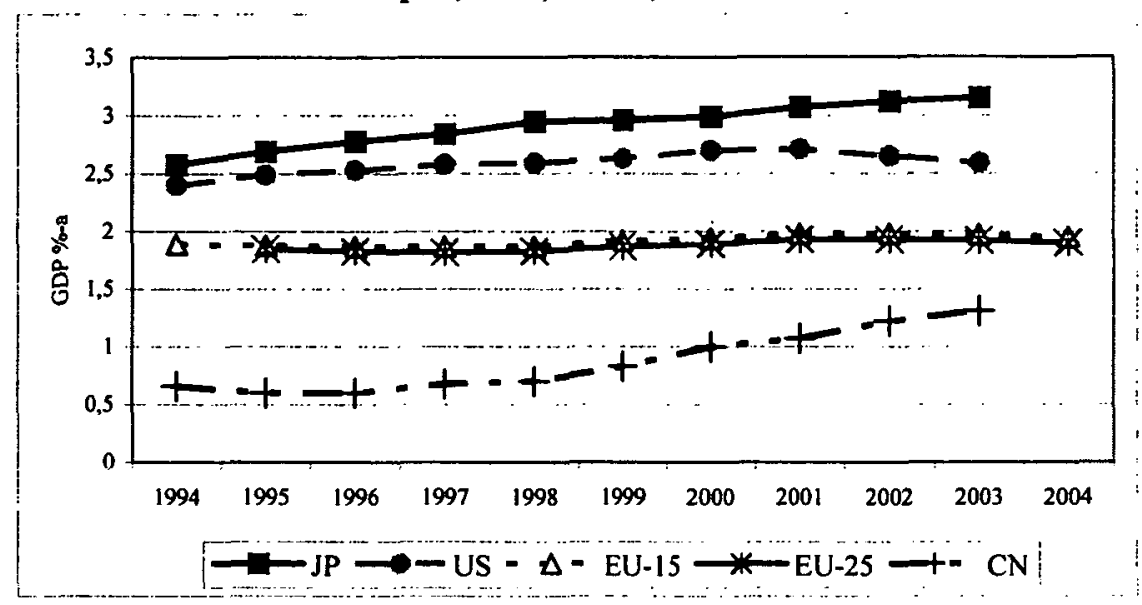

Forrás: (2)

Ismeretes, hogy a 2000. évi Lisszaboni Nyilatkozatban az EU tagállamai elé azt a becsvágyó célt állították, hogy az EU a világ legfejlettebb tudásalapú társadalmát és gazdaságát hozza létre 10 éven belül. Ennek érdekében a nemzeti $\mathrm{K}+\mathrm{F}$ ráfordítások $3 \%$-ra történő növelését javasolták.

Ez - ma már látható- irreális cél volt. A $3 \%$-os szintet jelenleg mindössze két tagország: Finnország és Svédország teljesíti, ezzel szemben a 27-ből 10 tagország még a GDP 1 százalékával sem tudja támogatni a tudományt. 2004 óta az Európai Unióban (EU-27) ennek a mutatónak az értéke monoton csőkkenő is, összefüggésben azzal, hogy az 1994 és 1997 évi bővítések során többnyire gazdaságilag kevésbé fejlett államok kerültek be.

Azon túl, hogy a GDP-ből a K+F-re fordított költséghányad mutatója kevés információt hordoz, másik nagy hibája az, hogy a lényegi ősszefüggésekre nem enged rálátást. Amit ugyanis egy nemzetközi összehasonlításnak e témakörben meg kellene mutatnia, az nem más, mint az anyagi erőforrás mértéke, a tagország anyagi erőforrás-potenciálja. Ezt azonban egy másfajta fajlagos mutatóval, itt következỏ példánkban az egy lakosra jutó $\mathrm{K}+\mathrm{F}$ ráfordítás összegével, mint általában nem ismert, általunk kidolgozott mutatóval célirányosabban lehet jellemezni. Az egy lakosra jutó $\mathrm{K}+\mathrm{F}$ ráfordítás mutatojának értéke szoros összefưggést mutat a nemzeti jövedelem egy före jutó összegének szintjével (2. ábra). Más szóval: csak azok az országok „engedhetik meg” a tudomány bỏkezü támogatását, amelyek ehhez elegendő nemzeti jövedelmet állítanak elő.

Ezt a gondolatot tovább folytatva, könnyủ belátni, hogy a két tényező között kölcsönös függés áll fenn: a $\mathrm{K}+\mathrm{F}$ tevékenység ugyanis az egyik fó eszköze lehet a nemzeti jövedelem növelésének. Tanulmányunk második részében a közvetlen gazdasági hasznú kutatások legföbb eredményességi mércéjével: a szabadalmi bejelentések denzitásának elemzésével és a GDP-hez történỏ hozzájárulásával foglalkozva igazolni is kívánjuk ezt az összefüggést. 


\section{2. ábra: Az egy lakosra jutó GDP és az egy lakosra jutó $K+F$ ráfordítás összefüggése}

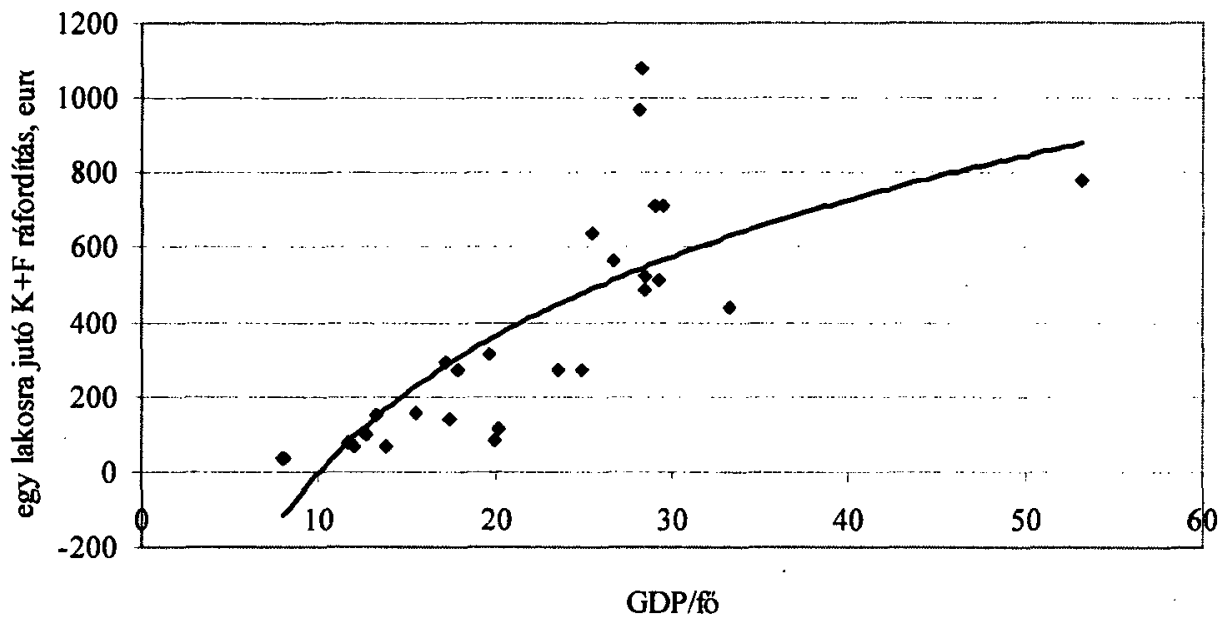

Forrás: (2) alapján saját számítások

A/2. A kutatási ráfordítások forrás szerinti megoszlásának vizsgálata következtetni enged arra, hogy a gazdaság piaci szereplöi, illetőleg a költségvetés milyen arányban járulnak hozzá a kutatási ráfordításokhoz ${ }^{3}$. Ez a megoszlási adat egyben arra is utal, hogy az üzleti szektor milyen mértékben hajlandó és képes finanszírozni a $\mathrm{K}+\mathrm{F}$ tevékenységet. Nyilvánvaló összefüggésben azzal is, hogy mit várhat attól. A 2005. évi adatok alapján azt a - nem meglepö - kővetkeztetést vonhatjuk le, hogy a magyarországi $K+F$ tevékenység finanszírozásában nem elsősorban az üzleti szektor, hanem a költségvetés játssza a meghatározó szerepet. Magyarországon a GDP-arányos, összesen 0,91 százalék nagyságú (2005. évi) $\mathrm{K}+\mathrm{F}$ ráfordításból 0,41 százalékpontos arányban részesedett az üzleti szektor, míg a kormányzati és felsőoktatási részesedés 0,50 százalékpontos volt.

Összehasonlításul: Az EU-27 átlagában a GDP-re vonatkoztatott $\mathrm{K}+\mathrm{F}$ ráfordítás aránya 2005ben 1,84 százalékos volt, amelyböl 1,17 százalékpontot finanszíroztak a gazdaság üzleti szereplői.(1) Az EU-27 1,84 \%-os, illetőleg 1,17 \%-os (üzleti) átlagadatát 6 tagország haladta meg: Dánia, Németország, Franciaország, Ausztria, Finnország és Svédország. Japán ide vonatkozó adatai: $3,33 \%$ összes és $2,54 \%$ üzleti, USA $2,62 \%$ összes és $1,82 \%$ üzleti ráfordítási arány.

Az üzleti élet szereplői természetesen piaci pozíciojuk és versenyképességük mértéke szerint vesznek részt a $\mathrm{K}+\mathrm{F}$ finanszírozásban. Az ebbỏl a szektorból származó $\mathrm{K}+\mathrm{F}$ ráfordítások terhét a legnagyobb méretü vállalkozások viselik. A 1. táblázatban bemutatjuk, hogy - a létszámmal jellemzett - vállalakozási mérethez tartozó vállalatcsoportok szerepe hogyan alakult az Európai Unió néhány tagországában és Magyarországon, 2004-ben.

A/3. A kutatási ráfordításoknak a különbözö kutatási szintek közötti megoszlásából további következtetések vonhatók le. Az „alapkutatások" ugyanis közismerten nem közvetlen gazdasági célúak, míg a kísérletes és fejlesztési kutatások igen. Így tehát ez utóbbiak magasabb arányából következtetni lehet az elvárható gazdasági haszonra is. Az „alkalmazott” 
kutatások pedig éppen a közvetlen gazdasági haszonnal járó kísérletes és fejlesztési kutatásokat alapozzák meg. Sajnos, ilyen megközelitést éppen a legnagyobb figyelmet érdemlő finn és svéd adatok hiảnya tesz lehetetlenné. Ám tanulságosak az EU-átlag, az ausztriai, az USA és Japán adatok is, összehasonlítva a hazaiakkal (2. táblázat) (3).

A statisztikai adatok szerint az EU-átlagához, fejlett kislélekszámú tagországaihoz és egyes ipari nagyhatalmakhoz képest Magyarországon az alapkutatások „túlsúlyos" arányt mutatnak, föként a kísérletes és fejlesztési - feltehetően tehát a közvetlen gazdasági hasznú - kutatások arányának rovására.

\section{1. táblázat: A K+F ráforditások alakulása az üzleti szektor külônbőzỏ méretú vállalkozásainál, 2004-ben}

\begin{tabular}{|c|c|c|c|c|c|c|}
\hline \multicolumn{1}{|c|}{$\begin{array}{c}\text { Vállalkozási } \\
\text { méret, fö }\end{array}$} & & EU-27 & $\begin{array}{c}\text { Magyar- } \\
\text { ország }\end{array}$ & $\begin{array}{c}\text { Cseh- } \\
\text { ország }\end{array}$ & Írország & $\begin{array}{c}\text { Finn- } \\
\text { ország }\end{array}$ \\
\hline \multirow{2}{*}{0 fö } & érték & 34 &. & 4 & 0 &.. \\
\cline { 2 - 7 } & $\%$ & 0,2 &. & 0,5 &. &. \\
\hline \multirow{2}{*}{$1-9$ fö } & érték & 1374 & 10 & 12 & 36 & 80 \\
\cline { 2 - 7 } & $\%$ & 1,1 & 3,3 & 1,7 & 3,1 & 2,1 \\
\hline \multirow{2}{*}{$10-49$ fö } & érték & 5872 & 20 & 62 & 219 & 268 \\
\cline { 2 - 7 } & $\%$ & 4,7 & 6,7 & 8,8 & 19,0 & 7,2 \\
\hline \multirow{2}{*}{$50-249$ fö } & érték & 14257 & 23 & 176 & 294 & 403 \\
\cline { 2 - 7 } & $\%$ & 11,5 & 7,7 & 25,1 & 25,5 & 10,9 \\
\hline \multirow{2}{*}{$250-499$ fö } & érték & 8700 & 23 & 81 & 174 & 338 \\
\cline { 2 - 7 } & $\%$ & 7,0 & 7,7 & 11,5 & 15,1 & 9,1 \\
\hline \multirow{2}{*}{$>500$ fö } & érték & 93346 & 220 & 365 & 426 & 2595 \\
\cline { 2 - 7 } & $\%$ & 75,5 & 74,0 & 52,0 & 37,0 & 70,4 \\
\hline \multirow{2}{*}{ Összesen } & érték & 123582 & 297 & 701 & 1150 & 3683 \\
\cline { 2 - 7 } & $\%$ & 100,0 & 100,0 & 100,0 & 100,0 & 100,0 \\
\hline
\end{tabular}

Forrás: (2)

2. táblázat: A kutatási ráfordítások megoszlása egyes országokban a kutatás különbözõ szintjei között (2003)

Mértékegység: százalék

\begin{tabular}{|l|c|c|c|c|}
\hline \multicolumn{1}{|c|}{ Ország } & $\begin{array}{c}\text { Alkalmazott } \\
\text { kutatások }\end{array}$ & Alapkutatások & $\begin{array}{c}\text { Kísérletes és } \\
\text { fejlesztési } \\
\text { kutatások }\end{array}$ & $\begin{array}{c}\text { Nem } \\
\text { azonosítható, } \\
\text { egyéb }\end{array}$ \\
\hline Magyarország & 30,1 & 31,1 & 33,7 & 5,2 \\
\hline EU-27 átlag & 35,2 & 23,1 & 41,4 & 0,2 \\
\hline Ausztria & 36,3 & 17,5 & 44,3 & 1,9 \\
\hline Írország & 32,3 & 19,9 & 48,0 &.. \\
\hline Dánia & 27,0 & 17,9 & 55,1 &.. \\
\hline Csehország & 30,0 & 25,1 & 44,9 &.. \\
\hline Japán & 21,3 & 12,6 & 61,0 & 5,1 \\
\hline USA & 23,2 & 18,5 & 55,4 & 3,0 \\
\hline Oroszország & 14,8 & 14,3 & 65,8 & 5,1 \\
\hline
\end{tabular}

Forrás:(3.) 
Ez a tény összefüggésben áll a kutatóhelyeknek a 6. pontban kifejtett megoszlásával. Jellemző egyébként, hogy a 2004-ben és 2007-ben csatlakozott országok mindegyikében alacsony az üzleti szféra által finanszírozott $\mathrm{K}+\mathrm{F}$ költséghányad és ezért általában magas a kormányzati és felsőoktatási költséghányad. Ez következik a nemzeti jövedelem fajlagosan alacsony szintjéböl is ezekben az országokban. A kormányzati és a felsőoktatási (az EU hivatalos szóhasználatában „közösségi”) források aránya 2004-ben az EU-25 átlagában 35 \%os volt, míg Finnországban 29 , Németországban 30, de Lettországban 79, Lengyelországban 71 , Magyarországon pedig $54 \%$-os volt.(4)

A/4. A K+F-ben foglalkoztatott munkavállalók száma; arányuk az összes foglalkoztatott létszámból, megoszlásuk az innovációs folyamatban játszott szerepük (mérnökök-kutatók, segéderők, stb.) és kutatóhelyük jellege (ipari, felsőoktatási, kormányzati, stb), illetöleg nemek szerint. A Központi Statisztikai Hivatal adatai szerint az összes kutatóhelyet figyelembe véve 1990-ben 59 ezer 723 fö dolgozott, 2007-ben azonban már csak 49 ezer 485 fö. Közülük 1990-ben 30256 fö dolgozott kutatói-fejlesztői munkakörben, 2007-ben pedig már 33059 fö. Országos átlagban nézve tehát az időszak kezdete és vége között romlott a kutató-nem kutató arány, éspedig az 1990. évi 1,00:1,94-ről 2007-ben 1,00:0,49-re. ${ }^{4}$ Ezt a mutatót előszeretettel alkalmazzák a hazai és az európai statisztikában. Az EU-27-ben mintegy 2 millió föt foglalkoztatnak a kutatás-fejlesztés területén ${ }^{4}$, amely létszámból $54 \% \mathrm{az}$ üzleti szférában, $31 \%$ a felsőoktatás és $15 \%$-a kormányzati munkahelyeken dolgozik. Magyarországon 23 ezer 239 fö ${ }^{4}$ a kutatásban foglalkoztatottak létszáma ${ }^{5}$, s ennek megoszlása a következő: az üzleti szférában dolgozik $32 \%$, a felsőoktatásban $33 \%$ és a kormányzati szférában 35 százalék. Az adatok az EU-átlag-adataihoz képest is aránytalanságot tükröznek, amelynek jellemzöje a felsőoktatási és föként a kormányzati foglalkoztatás magas, illetőleg az üzleti szférában történö foglalkoztatás alacsony aránya. (Japánban ezek az arányok a következök: üzleti szféra 65,4\%, felsőoktatás $7 \%$, kormányzati foglalkoztatás $25,2 \%$.)

Nem érdektelen a $\mathrm{K}+\mathrm{F}$-ben foglalkoztatott összlétszám megoszlása sem a munkavégzők két csoportja, éspedig a./ a kutatók-fejlesztők (mérnökök), illetőleg b./ az egyéb (segéd-) személyzet tekintetében. A kutatói létszámarány az EU-27 átlagában és Magyarországon közel azonos: 60, ill. 58 százalék, azzal, hogy a felsőoktatási kutatóhelyeken ennél az átlagnál azonosan magasabb (70, ill. $75 \%)$ a kutatói létszámarány.

A K+F-ben foglalkoztatottak, s ezen belül a kutatók-fejlesztők létszám-adatait az összehasonlíthatóság érdekében nem csak munkavállalói létszámban (fö) fejezik ki, de redukált (teljes munkaidőre számított) létszámban is megadják. A két adat hányadosa szerény véleményünk szerint - rendkívül beszédes: azt mutatja meg, hogy milyen a kutatás „személyi koncentrációja", a kutatóhelyeken foglalkoztatottak munkaidejük milyen hányadában folytatnak valódi kutatómunkát. A teljes létszámra vonatkoztatva a magyar adat 1:1,92; a kutatói állómányra nézve pedig 1:1,9-hez. Ez nagyvonalú megközelítésben azt jelenti, hogy a magyar $\mathrm{K}+\mathrm{F}$ személyi állománya munkaidejének csak felében foglalkozik a tudománnyal. A föhivatású kutatóhelyeken a teljes létszámra számítva az arány jobb (1,33:1hez, illetőleg a kutatóknál 1,29:1-hez), ám a felsöoktatási kutatóhelyeken lényegesen rosszabb: 3,33:1-hez, illetöleg a kutatóknál 3,17:1-hez. Ezeket az arányokat olyan szempontból tudnánk igazán minősíteni, ha egybe vethetnénk a kutatóhelyek és a kutatási témák számával. Erre azonban itt nincs lehetőségünk, mert a témák számáról publikus adat nem áll rendelkezésre. Érdekes megközelítés lehet azonban a kutatói létszám és a kutatási ráfordítások egymással történỏ szembeállitása. Ezt a mutatót sem használják az EU statisztikai gyakorlatában, bár éppen azt képes kifejezni, hogy az egyes tagországok 
tudományos személyzetének anyagi erőforrásokkal való ellátottsága mutat-e lényeges eltérést. $\mathrm{Az}$ adatok szerint (3. táblázat) az eltérés lényeges, szoros összefüggésben a tagállamok fajlagos nemzeti jövedelmével és a $K+F$ intenzitással.

3. táblázat: Egy fô (teljes munkaidős) kutatóra jutó kutatási ráfordítás az Európai Unió átlagában és egyes tagországaiban, 2004-ben

Mértékegység: fö, millió euro

\begin{tabular}{|c|c|c|c|c|c|}
\hline \multirow{3}{*}{ Ország } & \multicolumn{3}{|c|}{ Kutatói létszám } & \multirow{3}{*}{$\begin{array}{l}\text { Kutatási } \\
\text { ráfordítás, } \\
\text { millió euro }\end{array}$} & \multirow{3}{*}{$\begin{array}{c}\text { Egy fó } \\
\text { kutatóra jutó } \\
\text { ráfordítás }\end{array}$} \\
\hline & az üzleti & a közösségi & & & \\
\hline & \multicolumn{2}{|c|}{ szektorban, fö } & $g y$ & & \\
\hline EU-27 & 609407 & 625898 & 1235305 & 201020 & 162729,0 \\
\hline Csehország & 7297 & 8935 & 16232 & 1417 & 87296,9 \\
\hline Magyarország & 4309 & 10595 & 14904 & 838 & 56226,5 \\
\hline Ausztria & 16508 & 9311 & 25819 & 5784 & 224021,0 \\
\hline Finnország & 23397 & 17237 & 40634 & 5474 & 134714,7 \\
\hline Svédország & 28403 & 20139 & 48542 & 11109 & 228853,3 \\
\hline Németország & 161980 & 108410 & 270390 & 86356 & 319375,7 \\
\hline Franciaország & 106439 & 90276 & 196715 & 36396 & 185018,9 \\
\hline
\end{tabular}

"2005 évi adatok; " ezer euro/fö

Forrás: (2)

Az EU átlagánál lényegesen jobban ellátottak Németország és Franciaország kutatói, a kis tagországok közül pedig Svédország és Ausztria kutatói. Magyarországon az egy kutatóra jutó ráfordítás mindössze 1/3-a az EU-27 átlagának és 1/6-a Németországénak. Az új tagországok közül a táblázatban csak az újak átlagánál lényegesen jobban ellátott Csehországot szerepeltetjük; ott az egy kutatóra jutó ráfordítás az EU-27 átlagának mintegy a fele.

A/5. A kutatói létszám megoszlása a különbözỏ tudományterületek között. A 2004-es adatok szerint a közösségi (public) szektorban - teljes munkaidős létszámra számítva Magyarországon 10595 fö, az EU-25 tagországokban pedig 587549 fö müködött. Ez a létszám a 4. táblázat szerinti megoszlást mutatta a különböző tudományterületek között.

\section{4. táblázat: A közösségi szektorban“ müködő kutatók száma és megoszlásuk a különbőző tudományterületeken az EU-25-ben és Magyarországon (2004)}

\begin{tabular}{|l|r|r|r|r|}
\hline \multirow{2}{*}{ Tudományterületek } & \multicolumn{2}{c|}{ Magyarország } & \multicolumn{2}{c|}{ EU-25 átlag } \\
\cline { 2 - 5 } & \multicolumn{1}{c|}{ fó } & \multicolumn{1}{c|}{ százalék } & \multicolumn{1}{c|}{ fó } & százalék \\
\hline Természettudományi kutatások & 2990 & 28,2 & 179134 & 30,4 \\
\hline Müszaki-technológiai kutatások & 1284 & 12,1 & 126969 & 21,6 \\
\hline Orvosi kutatások & 1352 & 12,8 & 87702 & 14,9 \\
\hline Agrár-kutatások & 1026 & 9,6 & 29809 & 5,0 \\
\hline Társadalomtudományi kutatások & 1696 & 16,0 & 79819 & 13,6 \\
\hline Embertudományi kutatások & 2247 & 21,3 & 84118 & 14,4 \\
\hline Tudományterületek összesen & 10595 & 100,00 & 587549 & 100,00 \\
\hline
\end{tabular}

Felsôoktatásban és kormányzati kutatóhelyeken

Forrás: (4) 
Av6. A kutatóhelyek száma ${ }^{6}$ A kutatóhelyek száma Magyarországon 1990-ben 1256, 2007 ben pedig 2840 volt, az idöszak egészében folyamatosan, 17 év alatt 2,26 -szorosára növekedett. A kutatóhely jellegét tekintve az 5 . táblázaton bemutatott adatok szerint oszlott meg ez a szám a 2001 utáni időszakban. Számszerüleg tehát a felsőoktatási kutatóhelyek voltak (2/3-os arányban) és vannak (még mindig felerészben) többségben. Ez a helyzet két szempontból érdemel figyelmet: a./ kevés a vállalkozási kutatóhely, és a „fóhívatású” $K+F$ intézet is, amelyektől inkább várható a gazdasági hasznú kutatási eredmények kibocsátása; b./ szervezettség, elsősorban a kutatás személyi feltételeinek koncentrációja tekintetében éppen a felsőoktatási kutatóhelyek mutatják a legkevésbé kedvezỏ képet.

\section{5. táblázat: Magyarországi kutatóhelyek száma és megoszlása 2001-2007}

\begin{tabular}{|l|c|c|c|c|c|c|c|}
\hline \multirow{2}{*}{ Évek } & \multirow{2}{*}{$\begin{array}{c}\text { Kutató- } \\
\text { helyek } \\
\end{array}$} & \multicolumn{2}{|c|}{\begin{tabular}{c}
\multicolumn{2}{c|}{ Ebből: K+F intézet } \\
osszesen
\end{tabular}} & \multicolumn{2}{c|}{$\begin{array}{c}\text { Felsőoktatási } \\
\text { kutatóhelyek }\end{array}$} & \multicolumn{2}{c|}{$\begin{array}{c}\text { Vállalkozási } \\
\text { kutatóhelyek }\end{array}$} \\
\cline { 3 - 8 } & száma & aránya, \% & száma & aránya, \% & száma & aránya, \% \\
\hline 2001 & 2337 & 133 & 5,7 & 1574 & 67,3 & 630 & 27,0 \\
\hline 2002 & 2426 & 143 & 5,9 & 1613 & 66,4 & 670 & 27,7 \\
\hline 2003 & 2470 & 168 & 6,8 & 1628 & 65,9 & 674 & 27,3 \\
\hline 2004 & 2541 & 175 & 6,9 & 1697 & 66,8 & 669 & 26,3 \\
\hline 2005 & 2516 & 201 & 8,0 & 1566 & 62,2 & 749 & 29,8 \\
\hline 2006 & 2787 & 208 & 7,6 & 1552 & 55,6 & 1027 & 36,8 \\
\hline 2007 & 2840 & 219 & 7,8 & 1496 & 52,6 & 1125 & 39,6 \\
\hline
\end{tabular}

Forrás: (5)

A nemzetközi tendenciákkal összhangban már a 80-as évek óta Magyarországon is kormányzati cél volt az, hogy a felsőoktatási kutatóhelyek nagyobb szerepet játsszanak a $\mathrm{K}+\mathrm{F}$-ben. A rendszerváltás utáni átalakulások azonban ezt, az elvileg talán helyesnek tekinthető célt több szempontból is kétségessé tették.

A gyökeres társadalmi-gazdasági átalakulás ugyanis 1./ lerombolta a gazdasági célú kutatások eredményeit addig befogadó állami nagyvállalati szektort; $2 . /$ a kutatóintézetek privatizációja nem szolgálta a kutatás emberi erőforrásainak fejlesztését, ellenkezőleg: egy sor alkotóképes szakembert sodort egzisztenciális válságba (vagy külföldre); $3 . /$ a korábbi állami nagyvállalatokat felvásárló külföldi cégek nem kínáltak elegendő munkalehetőséget a kutatóknak-fejlesztőknek; 4./ ugyanakkor a gomba módra elszaporodó új felsőoktatási intézmények személyi állománya méltán tartott igényt az ủjonnan indított kutatási témák állami finanszírozására; 5./ ezek a kutatási témák - a nem kielégítő finanszírozási lehetőségek miatt is - jórészt közvetlen gazdasági hasznot vagy müszaki eredményt nem hozó, és nem is alapkutatás jellegüek voltak.

A kutatóhelyek számának és a kutatói létszámnak a fentiekben vázolt alakulása azzal a kővetkezménnyel járt, hogy Magyarországon az egy kutatóhelyre, illetőleg az egy fö -teljes munkaidőre számított - kutatói létszámra jutó kutatási költség igen alacsony. E dolgozat terjedelme nem teszi lehetővé, hogy itt érveljünk az egyébként a nemzetközi gyakorlatban sokszorosan igazolt kutatási költség-, és személyi koncentráció haszna mellett. Arra azonban rá kell mutatnunk, hogy a jelenlegi folyamat a mai Magyarországon a nemzetközi gyakorlattal és a racionalitással ellentétes tendenciájú dekoncentrációt erősíti.

B/1. A tudományos publikációk száma. A $\mathrm{K}+\mathrm{F}$ tevékenység eredményességének mérésére és számszerúsítésére hazánkban jelenleg leginkább ezt a mutatót használják. Hazai 
viszonylatban rendkivül sok és részletes adat áll rendelkezésre. Nem így állunk azonban az Európai Uniós adatokkal, ahonnan szinte egyáltalán nincsenek információink. Lehetséges, hogy ebben a szemléletbeli különbségek is megjelennek. Magyarországon az utóbbi években olyan szemlélet uralkodott el, amely a publikációt szinte a kutatás céljának - s ezzel együtt a sikeresség kritériumának - tekinti, eltekintve kissé a kutatási eredmény hasznosithatóságától. (Ez a felfogás vagy közszellem egymagában is mérlegelésre kell, hogy késztesse a pályakezdő kutatókat a tekintetben, hogy a közvetlen gazdasági célú kutatásokat válasszák-e életcéljukul, vagy inkább olyan tudományterületet, ahol a sikeresség kritériumai könnyebben teljesíthetök.)

\section{6. táblázat: A magyarországi K+F publikációk megoszlása a közlési hely szerint, 2007-ben}

\begin{tabular}{|l|c|c|}
\hline \multicolumn{1}{|c|}{ A közlési hely megnevezése } & $\begin{array}{c}\text { A publikációk } \\
\text { száma }\end{array}$ & $\begin{array}{c}\text { A publikációk százalékos } \\
\text { megoszlása }\end{array}$ \\
\hline Magyar nyelvü könyv és könyvfejezet & 6026 & 14,9 \\
\hline Cikk szakfolyóiratban & 17402 & 43,0 \\
\hline Elfogadott tudományos értekezés & 1468 & 3,6 \\
\hline Idegen nyelvü könyv és könyvfejezet & 1720 & 4,2 \\
\hline Akadémiai aktában megjelent cikk & 3085 & 7,6 \\
\hline Cikk külföldi szakfolyóiratban & 10714 & 26,7 \\
\hline Publikációk összesen & 40415 & 100,0 \\
\hline
\end{tabular}

Forrás: (5)

A magyarországi $\mathrm{K}+\mathrm{F}$ publikációk száma 2007-ben meghaladta a 40 ezret. Ennek nagyobb hányada (61,6 százaléka) magyar nyelvü, 38,4\%-a idegen nyelvü volt. Ez utóbbit önmagában is örvendetes fejleménynek tekinthetjük. A publikációk a 6. táblázat szerinti arányban oszlottak meg a publikáció helye szerint. A 7. táblázat adatai pedig azt mutatják be, hogy a publikációk hogyan oszlottak meg az egyes tudományterületek között.

7. táblázat: A magyarországi K+F publikációk megoszlása tudományterületek szerint, 2007-ben

\begin{tabular}{|l|c|c|}
\hline \multicolumn{1}{|c|}{ A tudományterület megnevezése } & $\begin{array}{c}\text { A publikációk } \\
\text { száme }\end{array}$ & $\begin{array}{c}\text { A publikációk százalékos } \\
\text { megoszlása }\end{array}$ \\
\hline Természettudományok & 9529 & 23,6 \\
\hline Műszaki tudományok & 3957 & 9,8 \\
\hline Orvosi tudományok & 5156 & 12,7 \\
\hline Agrártudományok & 2630 & 6,6 \\
\hline Társadalomtudományok & 10875 & 26,9 \\
\hline Bölcsészettudományok & 8268 & 20,4 \\
\hline Összesen & 40415 & 100,0 \\
\hline
\end{tabular}

Forrás: (5)

A tudományterületi sajátosságokból adódóan nagy a publikációs „intenzitás" különbsége az egyes tudományterületek között. Egy kutatóhelyre jutóan a különbség több, mint négyszeres, egy kutatóra jutóan pedig még nagyobb, akár kilenc-szeres is lehet (8. táblázat). Ez a „fajlagos” eltérés különös jelentőségre tesz szert éppen a felsőoktatás területén, ahol az oktatók minősítése szinte alig kapcsolódik oktatómunkảjuk minőségéhez, ám sokkal inkább publikációs intenzitásukhoz. (6) 
B/2. Egy másik, a kutatás és fejlesztés eredménvességêt jelző mutató a tagország vállalatainak innovációs aktivitását mutatia be. E mutató százalékban fejezi ki a bármilyen innovációt a vizsgált évben végrehajtó vállalkozások arányát. $\mathrm{Ez}$ tartalmilag nehezen követhetö mutató, minthogy az innovációk a vállalkozás életének minden területére kiterjedhetnek, ám ezek az innovációk koránt sem egyenértékủek. Elönye ezzel szemben az, egyetlen mutató használatával tehetünk összehasonlítást a tagországok vállalakozásai között az innovativitás tekintetében. Az EU-27 átlagában a vállalkozásoknak mintegy 43 százaléka volt innovatív, 65 százalékos aránnyal Németország vállalkozásai vezették a sort és Bulgária zárta azt 14 százalékos adattal. Magyarország a nagyság szerinti sorrendben a 23 . helyet szerezte meg, 20 százalék körüli értékkel.

\section{8. táblázat: Egy kutatóhelyre és egy kutatóra jutó publikációk száma az egyes tudományterületeken, 2007-ben}

\begin{tabular}{|l|r|c|c|}
\hline \multirow{2}{*}{ A tudományterület megnevezése } & \multicolumn{3}{|c|}{ Publikációk száma } \\
\cline { 2 - 4 } & Összesen & $\begin{array}{c}1 \text { kutatóhelyre } \\
\text { jutóan }\end{array}$ & $\begin{array}{c}1 \text { kutatóra } \\
\text { jutóan }\end{array}$ \\
\hline Természettudományok & 9529 & 20,5 & 2,17 \\
\hline Müszaki tudományok & 3957 & 4,8 & 0,64 \\
\hline Orvosi tudományok & 5156 & 15,8 & 3,19 \\
\hline Agrártudományok & 2630 & 9,10 & 2,09 \\
\hline Társadalomtudományok & 10875 & 18,9 & 4,12 \\
\hline Bölcsészettudományok & 8268 & 22,2 & 5,08 \\
\hline Összesen & 40415 & 14,2 & 2,32 \\
\hline
\end{tabular}

Forrás: (5)

A kizárólag az innovatív feldolgozóipari vállalatok körében mozgó adatgyüjtés azt mutatta be, hogy ezek milyen vállalati körre terjednek ki; müködésükben milyen szerepet játszik

- a high-tech termékek termelése

- a high-tech termékek forgalma,

- a high-tech termékek termelési értéke, illetve

- az igy előallított hozzáadott érték

Ugyanilyen információkat gyüjtöttek és dolgoztak fel a tudásintenzív, high-tech szolgáltatásokat nyújtó vállalatokról is. Magyarország high-tech feldolgozóipari vállalatai közül 6029, míg a tudásintenzív high-tech szolgáltatók közül 1095 vállalat adatai kerültek így feldolgozásra. Ezek a feldolgozóipari vállalatok 14,818 milliárd euro termelési értéket, illetve 2,899 milliárd euro hozzáadott értéket állítottak elö. A hozzáadott érték aránya tehát a 20 százalékot sem érte el, ami a high-tech szektorban kifejezetten alacsonynak mondható. A szolgáltatási területről gyüjtött vállalati adatok a következők: 1,964 milliárd euro termelési érték és 1,211.milliárd euro hozzáadott érték. A hozzáadott érték aránya itt 61 százalék, amelynek nagyságrendje nemzetközileg is elfogadható.

B/2. A high-tech és a medium-high-tech ${ }^{7}$ ágazatokban foglalkoztatottak aránya az összes (ipari, vagy szolgáltatási) foglalkoztatottból

Ezek a mutatók voltaképpen a tagország gazdasági struktúrájának a fejlettségét jellemzik és az innováció következményeinek is tekinthetök. Ok-okozati összefüggésben állnak azonban a müködő töke bevitellel, annak szerkezetével, a szellemi termékek termelésével és exportjával, stb. Ez a mutató csak korlátozottan alkalmas az innovációs fejlettség jellemzésére, hiszen 
például a high-tech iparban dolgozók magas aránya megvalósulhat a saját találmányi aktivitás alacsony szintje és a külföldi szabadalmak magas belföldi hasznosítási aránya mellett. $\mathrm{Az}$ ilyen jelenség magas arányú high-tech bérmunkára is utalhat, a belföldi találmányi kreativitás alacsony szintjén. Ugyanigy például az oktatásban (mint tudás-alapú szolgáltatásban) dolgozók magas aránya nem feltétlenül és egyértelmüen magas fejlettséget jelez ebben a szférában, de jelezhet pedagógusi túlfoglalkoztatást is. A 2004-ben és a 2007-ben csatlakozott tagországok vonatkozó fontosabb adatokat a 9. táblázat mutatja.

\section{9. táblázat: A high-tech ipar és a tudásalapú szolgáltatások fejlettsége a 2004-ben és 2007-ben csatlakozott egyes tagországokban}

\begin{tabular}{|l|c|c|c|}
\hline \multicolumn{1}{|c|}{ Megnevezés } & $\begin{array}{c}\text { EU-15 } \\
\text { átlaga }\end{array}$ & $\begin{array}{c}\text { A legjobb } \\
\text { csatlakozó }\end{array}$ & $\begin{array}{c}\text { A leggyengébb } \\
\text { csatlakozó }\end{array}$ \\
\hline $\begin{array}{l}\text { A high-tech és a medium-high-tech iparban } \\
\text { foglalkoztatottak aránya, \% }\end{array}$ & 7,4 & Szlovénia, 9,2 & Ciprus, 1,1 \\
\hline $\begin{array}{l}\text { A tudásalapú szolgáltatásokban dolgozó } \\
\text { munkavállalók aránya, \% }\end{array}$ & 33,3 & $\begin{array}{c}\text { Észtország, } \\
30,9 \%\end{array}$ & $\begin{array}{c}\text { Románia, } \\
12,8 \%\end{array}$ \\
\hline
\end{tabular}

Forrás: (8)

Ezeket az értelmezési korlátokat ismerve lássuk tehát a Magyarországra vonatkozó adatokat: A high-tech és a medium-high-tech ipari ágazatokban foglalkoztatottak aránya a teljes foglalkoztatásból (2002-ben) 8,5 százalékos volt, s ez a 2. legmagasabb érték a legutóbb csatlakozott országok körében. Magasabb, mint az EU-15 átlaga $((7,4 \%)$, és a régebbi tagországok közül csak Németország elözi meg a 11,4 \%-os arányával. A tudás-alapú szolgáltatásokban foglalkoztatott népesség aránya tekintetében a magyar fejlettség $(26,4 \%)$ gyengébb, mint az EU-15 átlaga (33,3\%), de a legutóbb csatlakozott $10+2$ tagország közül a 2. helyen áll. Ezek a foglalkoztatási arányok közvetlenül összefüggenek a betelepült nemzetközi vállalatok tevékenységi körével.

B/3 Az adott tagország high-tech és medium-high-tech termékexportia az összes ipari export százalékában. Az Európai Unió teljes exportjából a high-tech export 2005-ben 18,8 százalékkal részesedett. Magyarország kiviteléböl ennél is magasabb, 19,2 százalékos arányú volt a high-tech export. Az elöttünk járók, azaz az ennél is nagyobb arányú high-tech exportot megvalósító országok között egyaránt megtalálhatók az USA (26,1 százalék) és Kína is ( 28,4 százalék), de az olyan, újonnan csatlakozott kis országok is, mint Málta és Ciprus $(50,8$ ill. 31,6 százalék).

B/4. Végezetül a $\mathrm{K}+\mathrm{F}$ tevékenység eredményességének - szerény véleményünk szerint legfontosabb mércéiét, a szabadalmaztatást említiük. $E$ ponton valamelyest az EUcsatlakozás elötti évekre is visszatekintünk, mert ehhez az időszakhoz képest a jelenlegi szabadalmaztatási gyakorlat jelentös visszaesést mutat. A kutatás-fejlesztés eredményességét nézve a találmányokat különös fontossággal kezelik. A találmányok ugyanis közvetlen következményei a $\mathrm{K}+\mathrm{F}$ tevékenységnek. Továbbá: „mert csak a találmányok regisztrálására van lehetőség, a tudományos eredményeket... pontosan számba venni lehetetlen. A hazai találmányi bejelentések számának alakulása egy adott időszakban utal egy ország szellemi tőkéjére" - állítja Vedres (7). Elemzéseit 52 ország 1996 évi találmányi adatain végezte el, fajlagos (egy millió lakosra számított) adatokat használt, figyelembe vette a nemzeti jövedelmet és a Magyarországra vonatkozó következtetései a következők voltak: 
1995-ben 1 millió lakosra jutóan 111, míg 1996-ban már csak 83 szabadalmi bejelentést tettek. Ehhez viszonyítva lássuk a tízes világ-toplistát (1996 évi adatok): Japán 2860, DélKorea 1711, Monaco 900, Svédország 852, Németország 710, Finnország 679, Ausztrália 601, Dánia 480, USA 478, Egyesült Királyság 448. Magyarország a 83 szabadalmi bejelentéssel a világ-ranglistán a 27 . az EU-tagországok körében a 13. helyen állt. Érdemes figyelembe venni a külföldröl Magyarországra tett szabadalmi bejelentések ügyét is. 1996ban ezek száma 24147 volt, egy millió lakosra számítva 2414, azaz sokszorosa annak a számnak, amelyet ugyanabban az évben hazai bejelentők tettek.

A szabadalmi aktivitásban élenjáró nemzetek (1 millió lakosra jutó bejelentések számával jellemezve): Németország 281,1; Hollandia 243,3; Svédország 242,0; Finnország 221,1. Nem nehéz felfedezni, hogy ezek ugyanazok az országok, amelyek fajlagosan a legnagyobb összegeket fordítják a K+F-re. Magyarország 12,5-ös (1993 évi) értékkel az újonnan bekerült tagországok középmezőnyében helyezkedik el, de a 27 -es lista végén.

\section{Összefoglalás}

Eurostat és $\mathrm{KSH}$-adatok felhasználásával elemeztük a $\mathrm{K}+\mathrm{F}$ tevékenység hazai helyzetét és a $\mathrm{K}+\mathrm{F}$ tevékenység eredményességét. Arra a következtetésre jutottunk, hogy a hivatalosan használt és publikált mutatószámok rendszere kevéssé alkalmas a létező problémák bemutatására és stratégiai jellegü elemzésekre. A hivatalos adatok elemzése után levonható az a következtetés, hogy célszerü lenne hosszú statisztikai idősorok használata és a fajlagos fejlettséget jellemző mutatószámok kiterjedtebb alkalmazása. Dolgozatunk ilyen szemléletben mutatta be a magyarországi $\mathrm{K}+\mathrm{F}$ helyzetét.

Megállapítottuk, hogy a rendszerváltás utáni időszakban sem sikerült orvosolni olyan, a hazai $\mathrm{K}+\mathrm{F}$ hátrányát okozó bajokat, mint a kutatások nem kielégítő koncentrációja, az üzleti jellegü kutatások és általában a közvetlen gazdasági haszonnal kecsegtetỏ kutatások nem kielégítő aránya, a kutatási ráfordítások tudományterületek közötti megoszlásának problémái, stb. Több tekintetben kifejezetten rosszabb is a $\mathrm{K}+\mathrm{F}$ helyzete, mint a rendszerváltás elött volt, mindenek elött a $\mathrm{K}+\mathrm{F}$ szféra finanszírozása terén. A publikáció-centrikusság, mint az egyik, eredményességet jellemzö szemlélet eluralkodása háttérbe szoríthatja a $K+F-n e k$ azt az alapvető kapcsolati kettősségét, amely a gazdasághoz füzi, hogy ugyanis a gazdaság nemcsak a forrása, de elsőrangú haszonélvezője is kell, hogy legyen a $\mathrm{K}+\mathrm{F}$ tevékenységnek.

\footnotetext{
Jegyzetek

${ }^{1}$ E dolgozat szerzője, jelenleg professor emeritusként több, mint negyed százada készít elemzéseket a hazai és a külföldi innováció helyzetéröl, különös tekintettel az ipari vonatkozásokra, nemzetközi együttmüködésben is. Több jegyzet szerzöje és az Innováció, ill. az Európai Tanulmányok c. tárgyak elöadója a Szegedi Tudományegyetem Mérnöki Karán. A tanulmány fő megállapításai az „európai” tárgyak és az Innováció c. tárgy oktatása során hasznosithatók.

${ }^{2}$ A fogalmakat és azok tartalmát az EU-ban általánosan alkalmazott OECD-módszertan szerint értelmezzük. Forrás: Standard method proposed for research and expetrimental development surveys. Frascati Manual, OECD, 2002

${ }^{3}$ A „,kutatási ráfordítás” fogalma alatt a kutatási (mủködési) költségeket + a beruházási költségeket értik.

${ }^{4}$ Teljes munkaidőre számított létszám
} 
3 Az Eurostat adatai és a KSH adatai között nincsen teljes egyezés a kutatásban foglalkoztatottak száma és a kutatási ráforditások összege tekintetében sem. Így például a kutatásban foglalkoztatottak számát tekintve a KSH 49850 munkavállalót, illetőleg 25954 fôt adott meg 2007-re. (Kutatás és fejlesztés 2007. KSH, Budapest 2008, 5.p.)

' Általában nem képezi publikációk tárgyát (bár van ilyen magyarországi adat) az egy fö kutatóra jutó kutatási témák száma és az egy témára vagy egy kutatóra jutó kutatási ráfordítás összege sem. Ezek pedig stratégiai fontosságú kérdések, megkerülésük arra a nézetre utal, amely az erőforrások koncentrációját nem tartja fontosnak.

${ }^{7}$ A high-tech és a medium high-tech ágazatok és termékek rendszerezését és osztályokba sorolását az $O E C D$ végezte el $A$ különböző termelési és szolgáltatási tevékenységeket az OECD ajánlásai nyomán az Eurostat a következőképpen sorolta be: High-tech iparágak: irodagépek, számítógépek, rádió, televizió, kommunikációs berendezések gyártása, optikai és orvosi berendezések gyártása, óragyártás. Medium-high-tech iparágak: vegyipar, gépek és berendezések gyártása, elektromos gépek és berendezések gyártása, szállítóeszközök gyártása. Tudásalapú szolgáltatások: high-tech szolgáltatások (lásd fentebb), vízmüvek, légi közlekedés, pénzügyi közvetítés, ingatlanközvetítés, gépek és berendezések kölcsönzése, egyéb üzleti tevékenységek, oktatás, egészségügyi és szociális munka, rekreációs, kulturális és sport-tevékenységek.

\section{Források}

(1) Eurostat, R\&D Statistics - OECD-MSTI 2007-1; 15-16 p.

(2) Science, technology, innovation in Europe. Eurostat pocketbook, 2008 edition 2007

(3) Wilén, Hakan: R\&D activities and costs. Statistic in focus. 120/2007. Eurostat, 2007 jún.

(4) Wilén, Hakan: R\&D in higher education and government. Statistic in focus, 35/2007, Eurostat 2006 okt.

(5) Kutatás és fejlesztés 2007. KSH, Budapest, 2008

(6) Keczer, Gabriella: Hatékony belsỏ irányitási rendszer kialakításának lehetőségei a tradicionális magyar egyetemeken. PhD értekezés, Szent István Egyetem, Gödöllö, 2008

(7) Vedres, András: A világgazdaság és a szellemi tulajdon. Kik a jók, kik a jobbak, és hol vagy, Magyarország.

(8) Strack, Guido: Share of emloyment in knowledge-intensive services in the Acceding Countries still below EU-average. EU-Release, 2003 november 7

(9) Felix, Bernard: Patent statistics. Applying PATSTAT - A new generation of methodological concepts. Statistics in focus. 127/2008, 2008 február 